\title{
Knowledge of medical students on organ donation
}

\author{
Déssica Escribano Sampaio ${ }^{1}$ \\ D Danilo Euclides Fernandes ${ }^{2}$ \\ iD Gianna Mastroianni Kirsztajn ${ }^{3}$
}

\begin{abstract}
1. Faculdade de Medicina da Universidade Anhembi Morumbi, São Paulo, SP, Brasil 2. Mestre em Ciências, Departamento de Medicina da Universidade Federal de São Paulo, SP, Brasil 3. Professora Associada do Departamento de Medicina da Universidade Federal de São Paulo, São Paulo, SP, Brasil.
\end{abstract}

http://dx.doi.org/10.1590/1806-9282.66.9.1264

\section{SUMMARY}

OBJECTIVE: To analyze the spontaneous knowledge of medical students about organ donation.

METHODS: 518 students of a medical school in Sao Paulo city, from the first-year to internship, answered an objective questionnaire applied through electronic media to assess their spontaneous theoretical knowledge and organ donation awareness.

RESULTS: Organs that can be donated after brain death, such as the cornea, kidneys, heart, liver, and lung were mentioned by the students. Regarding in-life transplantation, they answered it was possible to donate mainly the kidney (91.3\%), part of the liver (81.1\%), and bone marrow (79.7\%). Although it was not expressive, we also noted that their knowledge gradually increased as they reached the end of the course.

CONCLUSIONS: Medical students knowledge on organ donation in life and after death was a little superior to 60\%. The students had limited exposure to this subject during the course ( $<40 \%$ of them before the internship). The authors suggest that students should be more exposed to the theme of "organ donation" in the medical curriculum.

KEYWORDS: Tissue and organ procurement. Students, medical. Health personnel. Education, medical. Transplantation.

\section{INTRODUCTION}

Transplantation, oftentimes, is the only option for patients with functional failure of certain organs. There is a lack of clarification and permanent programs on donation awareness, which generate waiting lists for organs and tissues, some of which can be derived from individuals alive or dead.

The potential donor needs to be identified, and the family of the donor must agree to the donation. If the health professionals and families do not have prior information on the subject, or if the deceased person never expressed their opinion on this matter, a negative answer becomes more common, considering the difficult moment experienced by the family ${ }^{1}$.

The criteria for the diagnosis of brain death, according to the Brazilian Federal Council of Medicine Resolution number 1.480/1997, are rigorous and involve 
neurological and complementary examinations ${ }^{2}$. After the diagnosis, the family goes through an interview with the purpose of providing them with objective and clear information on the possibility of the organs being donated for transplant. Once the donation is approved, the transplantation process begins with the harvesting of only the organs or tissues authorized by the family'.

According to the Brazilian Ministry of Health', the organs/tissues that can be donated after brain death are:

$\begin{array}{ll}\text { - Heart } & \text { • Cartilages } \\ \text { - Lungs } & \text { - Tendons } \\ \text { - Kidneys } & \text { - Menisci } \\ \text { - Liver } & \text { - Muscle fascia } \\ \text { - Pancreas } & \text { • Heart valves } \\ \text { - Intestine } & \text { • Vessels } \\ \text { - Skin } & \text { - Pericardium } \\ \text { - Bones } & \text { - Bone marrow } \\ \text { - Corneas } & \end{array}$

Multivisceral transplantation is also possible, and it consists of implanting the liver, pancreas, stomach, duodenum, and small intestine in the same individual. There are reports on transplantation of limbs, face, larynx, and trachea, among other things, but these are not carried out in Brasil2.

Living donor transplantation is also possible. A lot of care is taken to prevent any injury to the donor. The organs and tissues that can be donated by living individuals are ${ }^{3}$ :

- One of the kidneys

- Part of the lung

- Part of the liver

- Part of the pancreas

- Bone marrow

The Brazilian Public Health System (SUS) has the largest public program of transplants worldwide and is responsible for $87 \%$ of all organ transplantations in Brasil ${ }^{4}$. Currently, in Brasil, in order to be an organ and tissue donor, it is necessary to warn one's family about this wish. However, donation refusal is much greater than acceptance ${ }^{1}$. This is due to several factors, among them the lack of information on the importance of donation, the approach of health professionals with the families, sensationalist news stories about organ trafficking, among others ${ }^{2}$.

In a survey conducted in São Paulo, in 2017, considering 2,880 potential donors notified, among the causes for the donation does not being materialized, the most frequent (37\%) was the refusal by the family during the interview ${ }^{4}$. This is one of the reasons why it is so important for health professionals to know about organ donation since they will be the ones who will pass the information along to those responsible for the donation.

\section{METHODS}

This is a cross-sectional study conducted with medical students from the $1^{\text {st }}$ to the $6^{\text {th }}$-year of a faculty of medicine in the city of São Paulo (FM-SP). The subjects answered to a multiple-choice web-based questionnaire to evaluate their theoretical knowledge and investigate their awareness on organ donation. After responding the survey, informative material was sent to participants clarifying the aspects covered in the questionnaire.

The research project was submitted for consideration and approval by the Human Research Ethics Committee, and the subjects who participated signed the Informed Consent Form digitally.

The information collected in this survey were analyzed descriptively through their absolute and relative frequencies (percentage).

\section{RESULTS}

All the participants were students of a faculty of medicine in the city of São Paulo (FM-SP). The 518 students answered to a multiple-choice questionnaire, which was sent to 1,057 students whose contacts were available at the time of the application of the questionnaire. We obtained more answers from students who were in the years of the medical course, i.e., $30.9 \%$ in the $1^{\text {st }}$ year, $22.2 \%$ in the $2^{\text {nd }}$ year, $11.8 \%$ in the $3^{\text {rd }}$ year, $19.7 \%$ in the $4^{\text {th }}$ year, $8.5 \%$ in the $5^{\text {th }}$ year, and $6.9 \%$ in the $6^{\text {th }}$ year.

Most respondents were females (74.1\%). The predominant age group was $20-25$ years (57.53\%), followed by those younger than 20 years (26.6\%), 25-30 years (10.2\%), and over 30 years (5.6\%).

Regarding ethnicity, there was a predominance of whites (84.4\%), followed by other ethnicities as follows: brown (9.8\%), yellow (4.2\%), black (0.8\%), and indigenous (0.2\%). These individuals were predominantly Catholic (48.3\%), followed by those without religion (17.4\%), Evangelical (14.5\%), Spiritualists (12.7\%), others (6.4\%), and Jews (0.6\%). 
Most participants had no prior experience/exposure to situations of organ donation, corresponding to $73.5 \%$ of those who answered the questionnaire. Among those who had (26.4\%), 18.5\% reported that this exposure was theoretical, $1.3 \%$ that it was practical, $4.3 \%$ had practi$\mathrm{cal} /$ theoretical exposure, $0.8 \%$ had a role-play experience, and $4.6 \%$ went through any real situation. Among the students of the $1^{\text {st }}$ year, $17 \%$ answered that they had already had some exposure/experience related to organ donation; that figure was $16 \%$ in the $2^{\text {nd }}$ year, $21 \%$ in the $3^{\text {rd }}$ year, $38 \%$ in the $4^{\text {th }}$ year, $36 \%$ in the $5^{\text {th }}$ year, and $67 \%$ in the $6^{\text {th }}$ year, as shown in Figure 1.

Regarding the question about which organs can be donated after brain death, we found that most students knew that it is possible to donate the cornea (92.7\%), kidneys $(89.2 \%)$, and heart $(89.8 \%)$, followed by liver (84.6\%) and lung (79.2\%). The frequency with which the participants indicated other organs can be seen in Table 1.

Regarding the organs that can be donated in life, students answered that it was possible to donate mostly kidney (91.3\%), part of the liver (81.1\%), and bone marrow (79.7\%). The frequency of other donations can be seen in Table 1.

However, students were wrong in assuming that organs/tissues such as part of the pancreas (33.2\%), cornea $(20.8 \%)$, cartilage (18.1\%), liver (12.4\%), lung $(11.6 \%)$, muscle $(10.2 \%)$, heart (9.8\%), bones (9.7\%), pancreas $(7.5 \%)$, valve (5.6\%), multivisceral (3.9\%), and the skin $(0.6 \%)$ could be donated in life.
Overall, $63.7 \%$ of the students gave right answers regarding the organs that could be donated in life and $61.8 \%$ after brain death .

TABLE 1. ANSWERS PROVIDED BY MEDICAL STUDENTS TO THE QUESTIONNAIRE ON ORGANS THAT CAN BE DONATED.

\begin{tabular}{|c|c|c|c|}
\hline \multicolumn{2}{|c|}{$\begin{array}{l}\text { Organs that can be donated after } \\
\text { death, } n(\%)\end{array}$} & \multirow[b]{2}{*}{$(92.7 \%)$} & \multirow{2}{*}{$\begin{array}{l}p \text {-value } \\
0.00\end{array}$} \\
\hline Cornea & 480 & & \\
\hline Heart & 465 & $(89.8 \%)$ & 0.58 \\
\hline Kidney & 462 & $(89.2 \%)$ & 0.86 \\
\hline Liver & 438 & $(84.6 \%)$ & 0.31 \\
\hline Lung & 410 & $(79.2 \%)$ & 0.34 \\
\hline Skin & 397 & $(76.6 \%)$ & 0.52 \\
\hline Pancreas & 354 & $(68.3 \%)$ & 0.08 \\
\hline Part of the liver & 302 & $(58.3 \%)$ & 0.12 \\
\hline Bone marrow & 268 & $(51.7 \%)$ & 0.17 \\
\hline Bones & 226 & $(43.6 \%)$ & 0.00 \\
\hline Part of the lung & 213 & $(41.1 \%)$ & 0.39 \\
\hline Valve & 213 & $(41.1 \%)$ & 0.00 \\
\hline Part of the pancreas & 182 & $(35.1 \%)$ & 0.03 \\
\hline Cartilage & 162 & $(31.3 \%)$ & 0.05 \\
\hline Multivisceral & 148 & $(28.6 \%)$ & 0.13 \\
\hline Muscle & 136 & $(26.3 \%)$ & 0.01 \\
\hline \multicolumn{4}{|c|}{ Organs that can be donated in life, $n(\%)$} \\
\hline Kidney & 473 & $(91.3 \%)$ & 0.48 \\
\hline Part of the liver & 420 & $(81.1 \%)$ & 0.06 \\
\hline Bone marrow & 413 & $(79.7 \%)$ & 0.00 \\
\hline Part of the lung & 173 & $(33.4 \%)$ & 0.00 \\
\hline Part of the pancreas & 172 & $(33.2 \%)$ & 0.17 \\
\hline
\end{tabular}

aPearson's chi-square test.

FIGURE 1. REPORT OF THE MEDICAL STUDENTS ABOUT EXPOSURE TO THE ORGAN DONATION TOPIC.

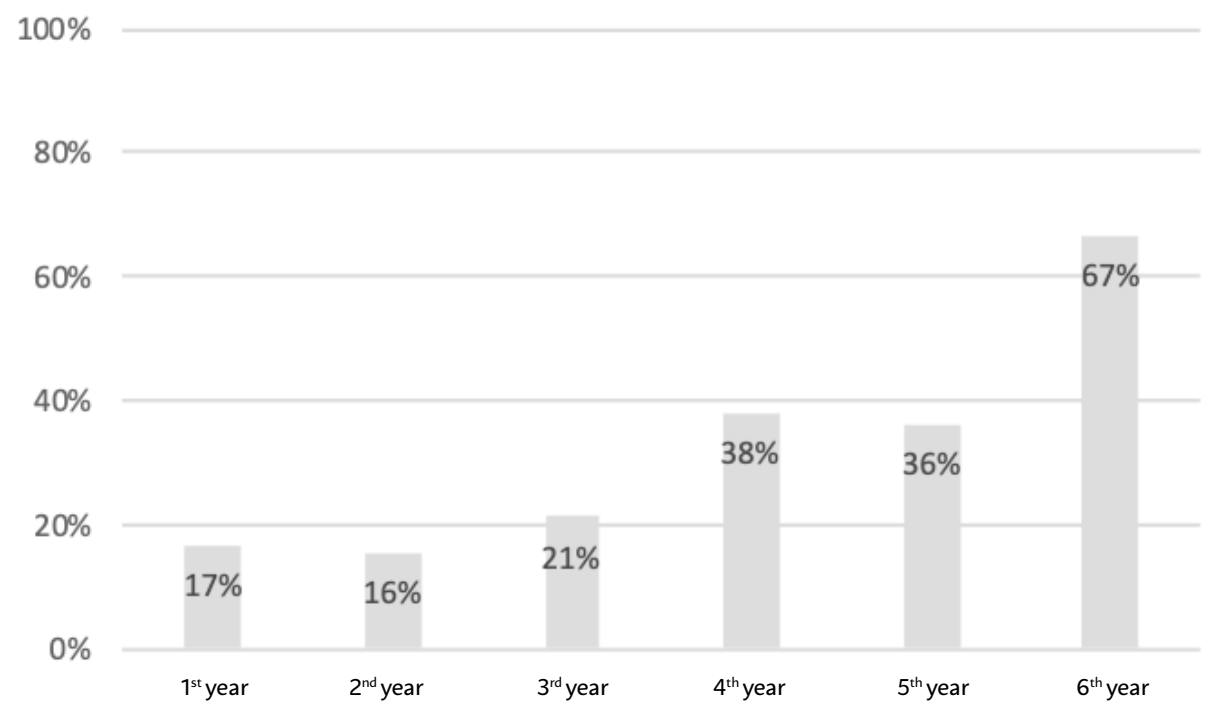


FIGURE 2. PERCENTAGE OF AFFIRMATIVE ANSWERS OF STUDENTS WHEN ASKED IF THEY HAD ALREADY TALKED TO THEIR FAMILIES ABOUT ORGAN DONATION VS. IF THEY WOULD REGISTER AS ORGAN DONORS.

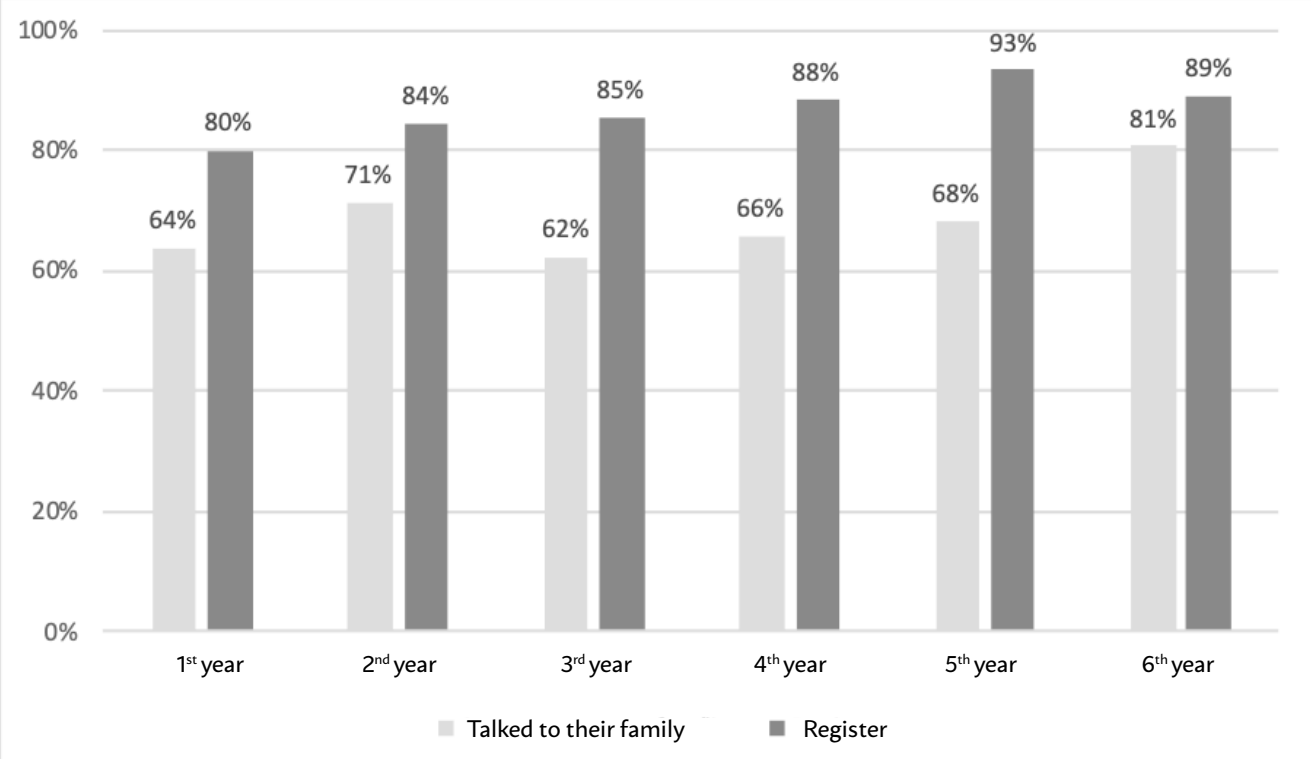

The percentage of students who said they would be able to explain to the relatives of a potential donor what is brain death was $82.6 \%$. According to them, the main challenge in organ donation currently is the fear of mutilation/deformation (33.6\%); in second place would be the understanding of brain death $(26.6 \%)$, followed by religious beliefs $(22.2 \%)$, no communication of the desire in life (15.4\%), discrediting of the health system (1.3\%), and others (0.8\%), among which were "prejudice", "remembrance of the deceased," "indiscriminate trade of organs," and the regulations that define who is the "representative" of the will of the deceased.

In addition, $67.2 \%$ of the participants stated that they have already talked to their families about organ donation (Figure 2) and, if there was an official record to become a donor after death, $84.9 \%$ would register themselves in it, $1.3 \%$ would not register, and $13.7 \%$ answered that they are not ready to make this decision.

\section{DISCUSSION}

In this study, the students of the $1^{\text {st }}$ to $4^{\text {th }}$ year of the medical course had greater participation than those of the $5^{\text {th }}$ and $6^{\text {th }}$ years. The authors consider that the low participation rate of the last two years may be due to the fact that these students are in an internship, with interests and obligations related to the practical activities of this period. The greater participation in the first years of the program certainly had an influence on the predominant age in this research, i.e., individuals from 20 to 25 years, followed by those younger than 20 years.

Caucasian and Catholic individuals were also predominant. The Instituto Brasileiro de Geografia e Estatística (IBGE) describes that $44.2 \%$ of the Brazilian population is composed of white individuals ${ }^{5}$ and $64.6 \%$ of Catholics ${ }^{6}$; thus, this distribution would be in line with the overall composition of our sample.

In Brasil, no religion is contrary to the donation of organs and tissues ${ }^{7}$. People, oftentimes, have their own interpretations of the doctrines imposed and use them as a justification for the refusal to donate ${ }^{8}$.

The questionnaires were sent to approximately 1,057 students of the medical course, and the response rate was $49 \%$. This rate is much than the rate of expected responses to online surveys, which is around $20 \%$, reinforcing the representativeness of this sample of students who participated in our study ${ }^{9}$.

Most students (73.55\%) had no previous experience with organ transplantation, and when there was exposure to the topic, it was mainly of a theoretical nature, related to lectures on the subject. When comparing the students who had exposure to the topic of organ donation, we noticed there was a relative increase along the 
years of study (Graph 1), although it was less than $40 \%$ up until the $5^{\text {th }}$ year.

Considering there was significant participation of students in this study, the topic does not appear to have been widely addressed during the medical program. This type of result is not surprising and is one of the reasons for the present study since medical students, future physicians, are essential in the guidance regarding organ donation in any area in which they will exercise their activities after having graduated.

No one got $100 \%$ of the answers right regarding the organs that could be donated. It is worth mentioning, however, that the questionnaire contained more rare alternatives for donation, such as multivisceral donation, because we considered that one of the functions of this study was to promote information about the various possibilities of donation. Students had greater knowledge about corneal, kidney, and heart donations. We also noticed that the knowledge gradually increased over the medical course, but not expressively, which shows the need for greater exposure of medical students to information about organ donation.

We emphasize that after obtaining the answers for all questionnaires, the students received a feedback message from the researchers containing information about the correct answers, thus increasing their knowledge on the subject.

The main challenge for organ donation, in the opinion of most students, was fear of mutilation. However, studies in this area show that the biggest problem in a transplantation program such as the Brazilian one is that people do not communicate their desire to donate their organs to their families during life.

We noticed that most participants had not yet talked to their families about the intention of becoming organ and tissue donors after death. It is known that such a simple attitude makes a huge difference in the moment relatives decide whether or not to allow the donation. On the other hand, it was interesting to observe that students said they would register as donors, and this answer was more frequent than the report of having already talked with their families about the subject; this same pattern was observed from the $1^{\text {st }}$ to the $6^{\text {th }}$ year (Figure 2).

The authors consider that the type of approach used in the present study has an educational role. It is important in disseminating information about organ donation, raising awareness about the problem of the shortage of organs and tissues for patients who need transplantations, and about the importance of this therapeutic resource to save or improve the quality of life of the patients who need them.

In other publications related to the knowledge of medical students about organ donation, we could not find any studies that evaluated the knowledge about which organs could be donated in life and after brain death. In addition, the number of participants in the present study was higher than any other research in the field. Some of these studies addressed issues related to general knowledge and beliefs about organ donation, understanding of brain death, and possible factors contrary to the donation ${ }^{7,10,11}$.

It is worth mentioning that the scarcity of information about organ donation is not something observed exclusively in Brasil. Studies have been conducted in Mexico, Canada, Hong Kong, and Turkey which also affirm the importance of improving the approach to the subject in medical schools ${ }^{12-15}$.

\section{CONCLUSION}

We consider that the knowledge of undergraduate medical students about organ donation was slightly above $60 \%$ regarding which organs and tissues could be donated in life and after death. The exposure of students to the topic during the medical course was low (involving less than $40 \%$ of them up until the $5^{\text {th }}$ year).

The results presented suggest that we should revise the curriculum of medical schools to increase information about organ donation during the course, preferably early on, in addition to teach medical students about the protocol for the diagnosis of brain death, which may optimize not only the training of health professionals but the participation of each individual as a multiplier of information in their daily lives, and, possibly, as a potential declared organ donor.

\section{Author's Contribution}

Jessica Escribano Sampaio: preparation of the project, recruitment of subjects, data collection, drafting of the paper.

Danilo Euclides Fernandes: data tabulation and analysis, support in the project management and methodology.

Gianna Mastroianni Kirsztajn: supervision of the project, drafting of the paper, formal analysis, methodology, analysis, and discussion of the data. 


\section{RESUMO}

OBJETIVOS: Analisar o conhecimento espontâneo dos graduandos de medicina sobre doação de órgãos.

MÉTODOS: A pesquisa foi realizada com 518 graduandos de medicina do $7^{0}$ ao $6^{\underline{0}}$ ano de uma faculdade de medicina da cidade de São Paulo (FM-SP). Os indivíduos responderam a um questionário de múltiplas alternativas aplicado por mídia eletrônica, para avaliar o conhecimento teórico espontâneo e o grau de conscientização sobre doação de órgãos.

RESULTADOS: Órgãos que podem ser doados após a morte encefálica, como a córnea, rins, coração, fígado e pulmão foram, em sua maioria, de conhecimento dos estudantes. Em vida, os alunos responderam que era possível a doação sobretudo de rim (91,3\%), parte do fígado (81,1\%) e medula óssea (79,7\%). Pudemos notar também que o conhecimento aumentou gradualmente no decorrer do curso, mas não de forma expressiva.

CONCLUSÕES: O conhecimento dos graduandos sobre doação de órgãos em vida e após a morte foi pouco superior a 60\%. A exposição dos alunos ao tema foi baixa durante o curso ( $<40 \%$ deles até o $5^{\circ}$ ano). Os autores sugerem que deveria haver maior exposição dos alunos ao tema "doação de órgãos" na grade curricular do curso médico.

PALAVRAS-ChAVE: Obtenção de tecidos e órgãos. Estudantes de medicina. Pessoal de saúde. Educação médica. Transplante.

\section{REFERENCES}

1. Brasil. Ministério da Saúde. Sistema Nacional de Transplante (SNT). Sistema de doação de órgãos. Doação de órgãos: transplantes, lista de espera e como ser doador [cited 2018 May 20]. Available from: http:// portalms.saude.gov.br/acoes-e-programas/doacao-transplantes-de-orgaos/ sistema-nacional-de-transplantes

2. Westphal GA, Garcia VD, Souza RL, Franke CA, Vieira KD, Birckholz $V R Z$, et al. Diretrizes para avaliação e validação do potencial doador de órgãos em morte encefálica. Rev Bras Ter Intensiva. 2016;28(3):220-55.

3. Hospital Israelita Albert Einstein. Transplantes. Doação de órgãos. [cited 2018 May 20]. Available from: https://www.einstein.br/especialidades/ transplantes/transplante-orgaos/doacao-orgaos

4. Associação Brasileira de Transplantes de Orgãos. Dimensionamento dos Transplantes no Brasil e em cada estado (2011-2018). Registro Brasileiro de Transplantes. 2018;XXIV(4):1-89.

5. Campos AC. População brasileira é formada basicamente de pardos e brancos, mostra IBGE. [cited 2019 Abr 29]. Available from: http://agenciabrasil. ebc.com.br/economia/noticia/2017-11/populacao-brasileira-e-formada-basicamente-de-pardos-e-brancos-mostra-ibge

6. Legado Brasil. Diversidade religiosa é marca da população brasileira. [cited 2019 Abr 29]. Available from: http:// legado.brasil.gov.br/noticias/cidadania-e-inclusao/2018/01/ diversidade-religiosa-e-marca-da-populacao-brasileira

7. Galvão FHF, Caires RA, Azevedo-Neto RS, Mory EK, Figueira ERR, Otsuzi
TS, et al. Conhecimento e opinião de estudantes de medicina sobre doação e transplante de órgãos. Rev Assoc Med Bras. 2007;53(5):401-6.

8. Pessoa JLE, Schirmer J, Roza BA. Avaliação das causas de recusa familiar a doação de órgãos e tecidos. Acta Paul Enferm. 2013;26(4):323-30.

9. Evans $\mid R$, Mathur A. The value of online surveys. Internet Res. 2005;15(2):195-219.

10. Reis FP, Gomes BH, Pimenta LL, Etzel A. Brain death and tissue and organ transplantation: the understanding of medical students. Rev Bras Ter Intensiva. 2013;25(4):279-83.

11. Batista CR, Kusterer LEFL. Conhecimento de estudantes de medicina sobre doação e transplantes de órgãos. J Bras Transpl. 2010;13(2):1309-15.

12. Sebastián-Ruiz MJ, Guerra-Sáenz EK, Vargas-Yamanaka AK, Barboza-Quintana O, Ríos-Zambudio A, García-Cabello R, et al. Actitud y conocimiento sobre donación de órganos de estudiantes de medicina de una universidad pública del noreste de México. Gac Med Mex. 2017;153(4):430-40.

13. Bardell T, Hunter DJ, Kent WD, Jain MK. Do medical students have the knowledge needed to maximize organ donation rates? Can J Surg. 2003;46(6):453-7.

14. Chung CK, Ng CW, Li JY, Sum KC, Man AH, Chan SP. Attitudes, knowledge, and actions with regard to organ donation among Hong Kong medical students. Hong Kong Med J. 2008;14(4):278-85.

15. Akkas M, Anık EG, Demir MC, Illhan B, Akman C, Ozmen MM, et al. Changing attitudes of medical students regarding organ donation from a University Medical School in Turkey. Med Sci Monit. 2018;24:6918-24. 